\title{
FIXED BED DOWNDRAFT GASIFICATION OF PAPER INDUSTRY WASTES
}

\author{
M. Ouadi ${ }^{\text {a*, }}$ J.G. Brammer ${ }^{\text {a }}$, M. Kay ${ }^{\text {b }}$, A. Hornung ${ }^{\text {a }}$ \\ ${ }^{a}$ European Bioenergy Research Institute (EBRI), \\ Aston University, Birmingham, UK \\ ${ }^{\mathrm{b}}$ Smithers Pira Ltd, Leatherhead, Surrey, UK \\ ouadim@aston.ac.uk,j.g.brammer@aston.ac.uk,m.kay@smithers.com, a.hornung@aston.ac.uk
}

\begin{abstract}
The two main wastes generated from secondary fibre paper mills are rejects (composed mainly of plastics and fibres) and de-inking sludge, both of which are evolved from the pulping process during paper manufacture. The current practice for the disposal of these wastes is either by land-spreading or land-filling. This work explores the gasification of blends of pre-conditioned rejects and de-inking sludge pellets with mixed wood chips in an Imbert type fixed bed downdraft gasifier with a maximum feeding capacity of $10 \mathrm{~kg} / \mathrm{hr}$. The producer gases evolved would generate combined heat and power (CHP) in an internal combustion engine. The results show that as much as $80 \mathrm{wt} \%$ of a brown paper mill's rejects (consisting of $20 \mathrm{wt} \%$ mixed plastics and $80 \mathrm{wt} \%$ paper fibres) could be successfully gasified in a blend with $20 \mathrm{wt} \%$ mixed wood chips. The producer gas composition was $16.24 \% \mathrm{H}_{2}$, $23.34 \% \mathrm{CO}, 12.71 \% \mathrm{CO}_{2} 5.21 \% \mathrm{CH}_{4}$ and $42.49 \% \mathrm{~N}_{2}$ (v/v \%) with a higher heating value of 7.3 $\mathrm{MJ} / \mathrm{Nm}^{3}$. After the removal of tar and water condensate the producer gas was of sufficient calorific value and flow rate to power a $10 \mathrm{kWe}$ gas engine. Some blends using rejects from other mill types were not successful, and the limiting factor was usually the agglomeration of plastics present within the fuel.
\end{abstract}

Keywords: Gasification, CHP, Energy, De-inking Sludge, Paper Wastes

* Corresponding author Tel: +44 (0) 1212043088 Fax: +44 (0) 1212043680

Email: ouadim@aston.ac.uk (M.Ouadi)

CEAC Building, Aston University, Aston Triangle, Birmingham, UK, B4 7ET

Abbreviations:

\begin{tabular}{|l|l|}
\hline CHP & Combined Heat and Power \\
\hline AN & Aylesford Newsprint Ltd \\
\hline SSK & Smurfit Kappa SSK \\
\hline KC & Kimberly Clark Flint \\
\hline TGA & Thermo Gravimetric Analysis \\
\hline HHV & Gross Heating Value \\
\hline GEK & Gasifier Experimenters Kit \\
\hline GCU & Gasifier Control Unit \\
\hline ROC & Renewable Obligation Certificate \\
\hline GC-TCD & Gas Chromatograph Thermal Conductivity Detector \\
\hline
\end{tabular}




\subsection{INTRODUCTION}

Secondary fibre (recycled) paper mills produce large amounts of waste. Approximately 1 million tonnes of de-inking sludge is produced in the UK each year [1], and depending on the size and type of mill over 10,000 wet tonnes per year per mill of plastics-dominated reject waste ("rejects") can be produced [2]. The current practice for the disposal of these waste streams is either by land-filling or land-spreading which is both costly and unsustainable. These mills are also significant users of energy in the form of both electricity and heat to power machinery and to dry paper sheets. As the cost for producing this energy increases year upon year, many UK based mills are finding it increasingly difficult to remain profitable, and this has lead to the closure of lower tonnage operations that manufacture commodity grade paper and board products [2]. There is therefore much interest in recovering useful thermal energy from these wastes.

In recent years there has been growing interest in the use of biomass and waste gasification systems for the production of combined heat and power (CHP) as this is considered to be one of the most promising renewable energy technologies [3], and key to the reduction of fossil $\mathrm{CO}_{2}$ emissions. Gasification is the conversion of a fuel source into a producer gas which is composed of mainly combustible gases $\left(\mathrm{CO}, \mathrm{H}_{2}\right.$ and $\left.\mathrm{CH}_{4}\right)$ that can be used in heat, power or combined heat and power applications [4]. The preferred configuration for small-scale distributed power generation $<5 \mathrm{MW}$ thermal is the Imbert type fixed bed downdraft gasifier [4] coupled to an internal combustion engine. This system offers advantages compared with traditional combustion systems such as higher efficiencies and reduced environmental impact, and is well-suited in terms of scale to the paper industry waste stream tonnages that are of interest here, which are often too low for other gasification technologies such as fluidised beds.

Although there has been extensive research carried out on the application of fixed bed downdraft gasification to process biomass and wastes in general $[5,6]$, very little work has been done specifically on downdraft gasification of paper industry wastes, with what studies there are being mainly focused on fluidised bed technologies [7, 8]. This can be explained by the problems for downdraft gasifiers of feedstocks with very high ash content such as de-inking sludge, and also feedstocks with high plastics content such as rejects which can lead to agglomeration above the throat [9]. One approach would be to co-gasify these materials with conventional biomass feeds. Some workers have looked at this for general waste plastics [9], but there has been no attempt to take this approach specifically with paper industry wastes.

The main objective of this study is to prove in principle that the blending of paper industry waste streams with wood chips is feasible in a fixed bed downdraft gasifier and further to determine the optimum blend which could be successfully gasified. Reject wastes (mainly plastics and paper fibre) are blended with de-inking sludge (mainly inks, dyes, fibres and inorganic fillers) and co-form wastes (mainly polypropylene and paper fibres) in varying proportions with wood chips in a Imbert type fixed bed downdraft gasifier. Experiments are carried out in a pilot scale $10 \mathrm{~kg} / \mathrm{hr}$ downdraft gasifier, with a view to ultimate application in $250 \mathrm{~kg} / \mathrm{hr}$ industrial scale units.

This work is being carried out under an industrial Co-operative Award in Science and Engineering (CASE) granted by the Engineering and Physical Science Research Council (EPSRC) in collaboration with three leading UK recovered fibre paper mills, Aylesford Newsprint, Smurfit Kappa SSK, and Kimberly-Clark Flint.

This paper presents details of the three main stages of the experimental work; firstly the pretreatment and characterisation of each waste stream to determine the proximate, ultimate compositions and energy content, secondly the assembling of the gasifier unit with appropriate instrumentation to record necessary gasification parameters such as flow rates, tar and gas 
compositions, and thirdly the detailed analysis of products formed from each gasification trial to determine the feasibility of each process and to establish the optimal process route.

\subsection{MATERIALS AND METHODS}

\subsection{Raw Materials}

Four different types of wastes generated from three secondary fibre paper mills were explored in this work. These were namely de-inking sludge and pulper rejects generated from Aylesford Newsprint's newsprint mill at Aylesford (AN), pulper rejects and co-form rejects (dry and wet wipes) generated from Kimberly Clark's tissue mill at Flint (KC) and pulper rejects generated from Smurfit Kappa SSK's brown paper mill at Nechells (SSK). Blends of these feedstocks were co-gasified with mixed wood chips acquired from a local UK based wood fuel supplier Midland Wood Fuel Ltd.

\subsubsection{De-inking Sludge}

When mixed office waste, news and pams feedstock enters a paper mill it contains a large fraction of inorganic substances including printing and writing inks, dyes, and fillers such as kaolin $\left(\mathrm{Al}_{2} \mathrm{O}_{3}, \mathrm{SiO}_{2}\right.$, $\left.\mathrm{H}_{2} \mathrm{O}\right)$, talc $\left(\mathrm{Mg}_{3} \mathrm{Si}_{4} \mathrm{O}_{10}(\mathrm{OH})_{2}\right)$, calcium carbonate $\left(\mathrm{CaCO}_{3}\right)$, and clays that are added to improve printability, smoothness, opacity and appearance of the finished paper product. De-inking sludge refers directly to the residues evolved from the de-inking process and generally contains high moisture which is reduced to approximately 35-40 wt \% after de-watering, high ash content between 40-70 wt \% which is predominately calcium based, and a low calorific value (4-7 MJ/Kg) [4]. The Smurfit Kappa (SSK) mill does not employ de-inking processes for the manufacture of brown paper; therefore no de-inking sludge is produced at this mill.

\subsubsection{Pulper Rejects}

When recovered paper or board is brought into a mill, it often contains large amounts of other waste, such as plastic, metal and glass. These waste fractions are rejected immediately from the process by initial screening which occurs after the initial stages of the pulping process. The wet reject material, which can contain moisture content in excess of $70 \%$, is then separated from the paper pulp and often placed in large skips or metal containers to dewater before being transported to landfill sites. The composition of these rejects varies widely and often changes depending on the paper manufacturer's specific process. For example, a brown paper and tissue mill's rejects will often contain mainly plastic and paper fibres, with lesser amounts of glass, and metals present, whereas a newsprint mill may see larger amounts of textiles, metal, glass and other general household waste. Generally reject material coming from a mill is quite heterogeneous and variable and it is this which imposes the requirement for costly pre-processing if the material is to be used as a fuel.

\subsubsection{Co-form Rejects (Dry and Wet Wipes)}

Co-form rejects are derived from non woven mills only and are essentially the rejected non woven materials used to make cleansing wipes often referred to as baby wipes. Cleansing wipes must meet stringent quality control checks before they can be sold and the rejected co-form material is essentially the wipes which do not meet these standards, and are therefore discarded from the manufacturing process. 
Dry co-form rejects refers to the cleansing wipes before moisture and other antibacterial reagents are added and are composed of approximately $30 \mathrm{wt} \%$ polypropylene and $70 \mathrm{wt} \%$ wood pulp fibres.

Wet co-form refers to the cleansing wipes after water and other cleansing ingredients have been added, they usually contain a moisture content of approximately $70 \mathrm{wt} \%$. At the $\mathrm{KC}$ mill the quantity of this particular waste stream is very small and would require a significant amount of surplus co-gasified fuel in order to operate an industrial scale fixed bed downdraft gasifier with a nominal throughput of $250 \mathrm{~kg} / \mathrm{hr}$.

\subsubsection{Mixed Wood Chips}

Approximately $500 \mathrm{~kg}$ of mixed wood chips acquired for trials was obtained from a local midland based wood fuel supplier (Midlands Wood Fuels Ltd) and was composed of mixed UK forest wood of mainly spruce origin and contained an initial moisture content of approximately $26 \mathrm{wt} \%$ (as received). After chipping the wood was of approximate dimensions $(15-40 \mathrm{~mm})$ length by (10-30 $\mathrm{mm})$ width and thickness (1-5 mm).

\subsection{Feedstock Pre-treatment}

\subsubsection{De-inking Sludge Pre-treatment}

Before experimentation each feedstock required some degree of pre-treatment. Approximately $700 \mathrm{~kg}$ of de-inking sludge was received from the AN mill. The feedstock as received contained an initial moisture content of approximately $35 \mathrm{wt} \%$ and was further dried down to a moisture content of $<3 \mathrm{wt}$ $\%$ using a rotary drum drier. Once the de-inking sludge was in a dry flaky form the material required an extra pelletisation step. This was achieved using a roll and die 9PK-200 $7.5 \mathrm{kWe}$ motorised pelletiser with total capacity of 100-150 kg/hr throughput. The pellets formed were of dimensions 6 $\mathrm{mm}$ diameter by $15 \mathrm{~mm}$ length. Figure 1 shows the dried de-inking sludge pellets produced by this work.

\subsubsection{Rejects Pre-treatment}

Approximately 1 tonne of each of the previously described rejects were acquired from each participating mill. The material as received initially contained a very high moisture content averaging $55 \mathrm{wt} \%$.

The pre-treatment of rejects began with the initial manual sorting of the material to remove non ferrous metals such as aluminium cans, glass bottles, stones and other large objects. The rejects were then further sorted on lines with overband metal detection to remove other ferrous metals such as staples and paper clips. The residual material consisting of mainly mixed plastics, and fibres were then size reduced using an industrial shredder, and then hot air blown dried for moisture reduction of $<20 \mathrm{wt} \%$. The rejects were then pelletised using an industrial pelletiser with $6 \mathrm{~mm}$ die and a compression ratio of 9:1. The pellets were subsequently dried down further to a moisture level of approximately 5-8 wt \%, and given a 'consolidation' re-pelleting to insure their integrity.

The final product was approximately $500 \mathrm{~kg}$ of each type of reject pellets with a total plastic content of 15-18 wt \%, $85 \mathrm{wt} \%$ paper fibre, a size range of $6 \mathrm{~mm}$ diameter by 15-20 mm length and an overall bulk density of $494 \mathrm{~kg} / \mathrm{m}^{3}$. An example of the reject pellets produced by this work is presented in Figure 2. 


\subsubsection{Wood Chip Pre-treatment}

Wood chips as received contained an initial moisture content of $26 \mathrm{wt} \%$ this was oven dried for a period of 12 hours at $70{ }^{\circ} \mathrm{C}$ in a Funditor tray drying oven with a maximum capacity of $20 \mathrm{~kg}$. The average moisture content after drying was approximately $9 \mathrm{wt} \%$. The wood was further sieved using a $2 \mathrm{~mm}$ mesh to remove fines. No further pre-treatment was necessary before gasification.

\subsection{Feedstock Characterisation}

Dry de-inking sludge fluff, wood chips and reject pellets were characterised in order to determine their proximate, and ultimate compositions and gross heating value.

\subsubsection{Moisture Content}

All moisture contents of the solids were determined using a moisture analyser (Sartorius MA35) with a programmed temperature of $105^{\circ} \mathrm{C}$. Total moisture content was determined gravimetrically by measuring the total weight loss of solid sample with increasing temperature until no further weight loss was measured at the programmed temperature.

\subsubsection{Proximate Analysis}

De-inking sludge was characterised by a proximate analysis to determine the moisture, volatiles, fixed carbon and ash present. This was carried by Thermo Gravimetric Analysis (TGA) in a Perkin Elmer Pyris 1 TGA device with auto sampler. Approximately $5 \mathrm{mg}$ of dried de-inking sludge was loaded into a tared crucible and pyrolysis of the sample was carried out under an inert atmosphere of $\mathrm{N}_{2}$ with a temperature programme of:

- Heating from ambient to $50^{\circ} \mathrm{C}$ at heating rate $5^{\circ} \mathrm{C} / \mathrm{min}$

- Hold for 5 minutes at $50^{\circ} \mathrm{C}$

- Heating from $50{ }^{\circ} \mathrm{C}$ to $105^{\circ} \mathrm{C}$ at heating rate $5^{\circ} \mathrm{C} / \mathrm{min}$

- Hold for 5 minutes at $105^{\circ} \mathrm{C}$

- Heating from $105^{\circ} \mathrm{C}$ to $900{ }^{\circ} \mathrm{C}$ at heating rate $25^{\circ} \mathrm{C} / \mathrm{min}$

- Hold for 15 minutes at $900{ }^{\circ} \mathrm{C}$

- Cooling to ambient at cooling rate $25^{\circ} \mathrm{C} / \mathrm{min}$

The weighted moisture content was determined at $105^{\circ} \mathrm{C}$, total fixed carbon was determined as the weight of solids after cooling and the total volatile content was obtained by difference.

The total ash content of de-inking sludge was determined by TGA combustion under the same programme temperature, using a purged atmosphere of air. After cooling the residual weight of ash was determined and recorded as a percentage of the original sample. Proximate analysis results are presented in Table 1 


\subsubsection{Ultimate Analysis}

Samples of the dried de-inking sludge were analysed externally by Medac Ltd using a Carlo- Erba EA1108 CHNS-O analyser by total oxidation. Elemental compositions $(\mathrm{C} \mathrm{H} \mathrm{N} \mathrm{O}, \mathrm{S}, \mathrm{Cl})$ are presented in Table 1

\subsubsection{Gross Heating Value (HHV)}

The gross heating value in $(\mathrm{MJ} / \mathrm{Kg})$ of the dried de-inking sludge was determined using a Parr 6100 bomb calorimeter, and was verified using the unified correlation for fuels developed by Channiwala et al [10]

$\mathrm{HHV}(\mathrm{MJ} / \mathrm{kg})=0.3491(\mathrm{C})+1.1783(\mathrm{H})+0.1005(\mathrm{~S})-0.1034(\mathrm{O})-0.0151(\mathrm{~N})-0.0211(\mathrm{~A})$

Where $\mathrm{C}, \mathrm{H}, \mathrm{S}, \mathrm{O}, \mathrm{N}$ and $\mathrm{A}(\mathrm{ash})$ are the mass fractions from the ultimate analysis expressed as percentages.

\subsubsection{Reject and Wood Chips Characterisation}

Due to the heterogeneous nature and variability of the reject pellets, average compositional values were taken over a total sample size of $200 \mathrm{~g}$. Reject pellets and wood chips were characterised externally by Marchwood Scientific Services Ltd to determine the average proximate and ultimate compositions and heating value. The characterisation results of the reject fuel pellets and wood chips are presented in Table 1.

\subsection{Gasification Experiments}

The gasification of de-inking sludge, rejects and wood chips in this work was carried out using a 10 $\mathrm{kg} / \mathrm{hr}$ fixed bed downdraft gasifier. The unit also known as the Gasifier Experimenter's Kit (GEK) was originally designed and manufactured by All Power Labs in the USA. The unit which operates under negative pressure using a venturi air ejector is shown in Figure 3 and is composed of a hopper (9), feed dryer (3), motorised auger (11), gasifier (1), cyclone (2), carbon absorption filter (10) and swirl burner (8).

In order to determine the relative mass balance of each experiment it was necessary to modify and install further instrumentation. This included a calibrated glass hopper for measuring feedstock flow rates, a calibrated air rotameter for air inlet flow rates, k-type thermocouples for temperature measurements, a calibrated orifice plate for gas outlet flow rates and a gas sampling line for tar water and gas compositional measurements. All recordable data were sent to a Gasifier Control Unit (GCU) and logged every second. In all experiments the gasification medium used was pre-heated air and the pre-heat was derived from a heat exchanger jacket between the hot producer gases leaving the reactor and ambient air entering the reactor.

Before each experiment the gasifier was cleaned to remove tar fouling, ash and char before being reassembled. At the start of each run the bed of the gasifier was filled with approximately 2-3 kg of fresh wood charcoal and the hopper filled with the prepared feedstock of known weight. The unit was then sealed gas tight to ensure no air leaks and this was tested for by performing a cold run before each experiment. The experiments were initiated by opening the venturi ejector valve, opening an ignition port on the gasifier and using a propane burner to light the gasifier bed. After ignition was achieved feedstock was fed into the gasifier from the hopper and the reactor was then left to reach 
gasification temperatures of approximately $\left(800-1000^{\circ} \mathrm{C}\right)$ at the oxidation zone, and once gasification was within this temperature range the flare was ignited. The nature of the design of the GEK unit is such that temperature is controlled by altering the air flow rate entering the gasifier. Therefore at start up the air inlet flow rate was maintained at $10 \mathrm{~m}^{3} / \mathrm{hr}$, however as the experiment proceeded the air flow rate was either slightly increased or decreased to stabilise fluctuations in gasification temperature. Each run lasted approximately 3-5 hours and depending on the material used consumed density of the feedstock by the reduction of hopper volume.

\section{4 .1 Tar Analysis}

Tar was quantified by a tar sampling system developed by CEN [11] in which an isokinetic sample of producer gas is removed from the gasifier and routed through a series of gas wash bottles that condense the tars under low temperatures and by the use of a propan-2-ol extraction solvent. A rotary evaporator was then used to separate the tar/propan-2-ol mixture and the tar was subsequently quantified gravimetrically. The remaining clean producer gas was then routed through a mass flow meter and then directly into a GC-TCD for detection and quantification (Figure 4).

\subsubsection{Water Condensate Analysis}

Water condensate after the extraction of tar was determined by a V20-Compact volumetric KarlFischer titration unit using a Hydranal composite $5 \mathrm{~K}$ titrant.

\subsubsection{Producer Gas Analysis}

Gas analysis was carried out using a Gas Chromatograph Thermal Conductivity Detector (GC-TCD) in a Hewlet Packard HP-5890 series II device with 60/80 Carboxen 1000 column. Oven temperature was pre programmed to an initial temperature of $35^{\circ} \mathrm{C}$ and ramped to $225^{\circ} \mathrm{C}$ at a rate of $20{ }^{\circ} \mathrm{C} / \mathrm{min}$. Helium with a flow rate of $30 \mathrm{ml} / \mathrm{min}$ was used as the carrier gas.

\subsection{RESULTS AND DISCUSSION}

\subsection{Feedstock Characterisation Results}

Table 1 shows the proximate, ultimate and gross heating value of all feedstocks used in gasification trials. It is observed from the feedstock characterisation results in Table 1 that the de-inking sludge has a very low calorific value of $6.4 \mathrm{MJ} / \mathrm{Kg}$ and a very high ash content of $51.6 \mathrm{wt} \%$ which would require the need for a continuous ash removal system in an industrial scale fixed bed downdraft gasifier. Further analysis into the composition of the de-inking sludge ash was carried out and revealed that it was composed largely of calcium oxide. Therefore it is suspected that de-inking sludge ash may share similar properties to that of calcined limestone or dolomite which would make its use as a solid medium in a fluidised bed gasifier of interest, with catalytic properties for the cracking of tars at elevated temperatures $\left(>800{ }^{\circ} \mathrm{C}\right)$. Alternatively it has also been shown that the mineral ash-forming content of de-inking sludge can be further reduced before gasification or combustion by as much as $65 \mathrm{wt} \%$ if initially pre-treated with an acid; both $\mathrm{HCl}$, and $\mathrm{H}_{2} \mathrm{SO}_{4}$ have been shown to work well. Acid washing pre-treatment of biomass for ash-forming mineral removal is well documented $[12,13,14]$ and its application to pre-treat de-inking sludge is also feasible in principle, however the effect on the gasification products is unknown and requires further work. 
Also notable from Table 1 is the similarity between the dry and wet co-form material with the

only significant difference being higher moisture content of the wet co-form which is $7 \%$ higher than the dry co-form material, this is due to the difficulty of removing water during the drying process.

The pulper reject fuel pellets all have a higher gross heating value averaging $22 \mathrm{MJ} / \mathrm{Kg}$ as compared with $15.4 \mathrm{MJ} / \mathrm{Kg}$ for mixed wood chips, and this is due to the presence of plastics within the pellets. The rejects also have a much lower ash content compared to de-inking sludge, but the ash is significantly higher than wood chips. From Table 1 the total volatile fraction and fixed carbon content of the pulper reject pellets is similar to that of wood chips. Chlorine content of the rejects is observed to be higher than that of wood chips and this is thought to be as a result of residual PVC material in the plastic pellets.

\subsection{Gasification Results}

Table 2 shows the feedstock blends tested in gasification trials along with the performance status of the trials. From Table 2 is observed that unsuccessful trials were in most cases from the testing of AN and $\mathrm{KC}$ rejects and co-form pellets, and this is thought to be largely due to the levels of hard plastics present within the pellets which caused agglomeration and blockage within the gasifier. The most successful trials were from SSK rejects. Initial trials attempted to gasify the reject pellets without the use of wood chips as a co-gasified blend. However the gasifier suffered from agglomeration problems caused by melting of plastics. Agglomeration was found to be mainly within the pyrolysis zone of the gasifier at moderate temperature levels; as the plastics reach this zone they become soft and extremely sticky causing bridging and binding above the gasifier throat, and this subsequently causes increased pressure drop within the gasifier unit and leads ultimately to unsuccessful gasification. One of the most important factors when using the downdraft gasifier is the ability for feedstock to freely move through the unit by gravity. Note this would not be a problem in fluidised bed gasifiers, where the heating rate is much higher and particles entering the gasifier reach full reactor temperature almost instantaneously. Figure 5 illustrates the extent of the plastics agglomeration encountered within the gasifier unit.

The focus of subsequent trials was to determine to what extent the pellets could be co-gasified with wood chips before agglomeration occurred. Trials number 1, 2 and 3 shown in Table 2 focused on the gasification of AN rejects with wood chips, however the maximum blend which could be achieved in these cases was only $20 \mathrm{wt} \%$ rejects with $80 \mathrm{wt} \%$ wood chips. Trial number 4, 5 and 6 focused on introducing AN de-inking sludge to the blend whilst keeping the 1:4 weighted ratio between the rejects and wood chips constant. The de-inking sludge blend was then gradually increased to determine the maximum blend of rejects and de-inking sludge which could be co-gasified with wood chips. The maximum blend which was achievable in this mix was found to be $40 \mathrm{wt} \%$ of de-inking sludge; at higher percentages the ash content of the gasifier bed rose to levels which were unacceptable for gasification, with limited carbon content and excessive pressure drop.

The most successful trials were the blending of the SSK reject pellets with wood chips (trial numbers 7, 8, 9 and 10 in Table 2). The most successful of these was the blending of $80 \mathrm{wt} \%$ SSK pellets with $20 \mathrm{wt} \%$ wood chips. When this test was carried out the feedstock gasified successfully for several hours with no performance problems, and a consistent flare was achieved throughout the duration of the trial. The temperature of the gasifier bed was maintained at approximately $1000{ }^{\circ} \mathrm{C}$, producer gas outlet temperature measured at the gasifier exit averaged $450{ }^{\circ} \mathrm{C}$, pressure differential between the internal jacket of the gasifier and atmosphere was approximately $650 \mathrm{~Pa}$ and total pressure drop across the system recorded between the carbon filter and the gasifier was $500 \mathrm{~Pa}$. Air intake averaged $7 \mathrm{~m}^{3} / \mathrm{hr}$ and total feed consumed over the duration of the run was $20 \mathrm{~kg}$. 
It is the composition of this particular feedstock which is thought to be the key parameter for its successful gasification. It contained a lower proportion of hard plastics than the other rejects tested. In trial number 12, rejects and co-form dry and wet wipes were blended together in the proportions that they arise from the $\mathrm{KC}$ mill, and then co-gasified with wood in a proportion that corresponded to the full utilisation of the $\mathrm{KC}$ waste streams over a year in a $250 \mathrm{~kg} / \mathrm{hr}$ gasifier. However the level of plastics present was again too high for successful gasification, causing major agglomeration. No further testing of this waste stream was carried out.

\subsubsection{Producer Gas Compositions}

Table 3 shows the composition of producer gas formed from the successful gasification trials. Overall the quality of the producer gas from each successful run was high, and when mixed with air and ignited a strong, consistent flare was achieved.

From Table 3 it is observed from trial number 1 that co-gasified AN reject pellets give a volume composition of approximately $16.2 \% \mathrm{H}_{2}, 45 \% \mathrm{~N}_{2}, 24.4 \% \mathrm{CO}, 2.4 \% \mathrm{CH}_{4}$ and $12 \% \mathrm{CO}_{2}$ and this is similar to compositions found with wood gasification [15].The heating value of the gas is also comparable to wood gasification (typically $4-6 \mathrm{MJ} / \mathrm{Nm}^{3}$ ). Due to the presence of a large fraction of $\mathrm{CaCO}_{3}$ in de-inking sludge ash, the effect of adding increasing amounts of de-inking sludge in trials 4 , 5 and 6 had the effect of increasing the $\mathrm{CO}_{2}$ from the calcination reactions occurring above $700{ }^{\circ} \mathrm{C}$, and this consequently lowered the calorific value of the producer gas.

Smurfit Kappa rejects (SSK) trials 8 and 10 produced the highest calorific value gases overall (8 and $7.3 \mathrm{MJ} / \mathrm{Nm}^{3}$ respectively) with generally elevated levels of $\mathrm{H}_{2}$ and other combustible gases as well as lower amounts of $\mathrm{N}_{2}$, and the producer gas formed was of sufficient calorific value and flow rate to power a $10 \mathrm{kWe}$ gas engine.

In all trials high levels of $\mathrm{N}_{2}$ were present in the producer gas as a result of using air as the oxidising medium. Using oxygen enriched air as the oxidising medium would reduce the level of $\mathrm{N}_{2}$ present and thus would increase the calorific value of the gases produced, although a cost would be associated with the enrichment.

$\mathrm{CO}_{2}$ produced in all runs did not exceed $17 \mathrm{v} / \mathrm{v} \%$ and a proportion of the $\mathrm{CO}_{2}$ produced is considered to be carbon neutral as it is derived from wood chips and paper fibres which originate from wood pulp (a carbon neutral source of biomass). It is also observed from Table 3 that runs which included de-inking sludge as a fuel blend produced high levels of $\mathrm{CO}_{2}$. This is thought to be the result of calcination reactions of $\mathrm{CaCO}_{3}$ present within de-inking sludge ash which occur above $700{ }^{\circ} \mathrm{C}$ to form $\mathrm{CaO}$ and $\mathrm{CO}_{2}$. Increasing the level of $\mathrm{CO}_{2}$ in the producer gas has a diluting effect and reduces the overall gas calorific value. Therefore to achieve a maximum product gas heating value the deinking sludge content should be kept to a minimum.

\subsubsection{Tar and Water Condensate Measurement}

Table 4 shows both the tar and water content produced from each successful gasification trial. After each run the gasifier was disassembled and some traces of tar deposits in outlet piping and especially around the venturi ejector were found. Water condensate formation in outlet piping was found to be minimal, which was due to the extensive drying pre-treatment. Tar and water condensate formation during each run was also measured immediately, and from Table 4 the average tar content was 3 $\mathrm{g} / \mathrm{Nm}^{3}$ for the AN tests and $3.3 \mathrm{~g} / \mathrm{Nm}^{3}$ for the SSK tests, and the average water condensate content was found to be $14.7 \mathrm{~g} / \mathrm{Nm}^{3}$ and $16 \mathrm{~g} / \mathrm{Nm}^{3}$ respectively. These tar contents are higher than those observed from wood gasification which are typically $1-2 \mathrm{~g} / \mathrm{Nm}^{3}$ in this type of gasifier [16]. However at full scale careful control of gasification temperatures along with the use of downstream tar clean up 
equipment such as scrubbers, filters or tar crackers has been shown to reduce the amount of tar in the producer gas to acceptable levels for use in an engine. In this work tar clean up was achieved using a carbon absorption filter, but tar levels downstream of the filter were not measured.

\subsubsection{Gasification Mass Balance $(\mathrm{Kg} / \mathrm{hr})$}

Table 5 shows the mass balance and closures of each successful gasification trial. The closures from the mass balance presented in Table 5 were in most cases within the limits of experimental error, which for the purpose of this work was set at $10 \%$. Closures outside this margin were largely due to instrumentation error.

The general applicability of observations from the present work depends on the degree to which it can be assumed that the performance of the GEK gasifier is representative of full scale. This is not clear. The design of the GEK is based on the Imbert concept which is common to most successful downdraft gasifier designs, and effort has been made in the design to limit thermal losses by using recuperative heat exchange. There is therefore no obvious reason to suppose that the temperature time history seen by a feedstock particle will change significantly on scale up, and the behaviour of a particle in response to a given temperature time history should also be unaffected (it is the same material). However, the important issue is whether the tendency of the softening plastics within the particle to cause agglomeration with neighbouring particles and form a blockage remains the same. The tendency to agglomerate would be related to the amount of surface contact between particles, which would in turn be related to properties such as porosity and surface-to-volume ratio which change with scale, but the present work has not allowed this to be explored.This must be borne in mind in conjunction with the following concluding remarks.

If nonetheless the performance of the GEK gasifier is taken as representative of full scale operation for any fixed bed downdraft gasifier design, then it can be concluded that the use of fixed bed downdraft gasification to convert paper industry wastes would be practical only for reject wastes produced from the SSK brown paper mill, and a small amount of wood would need to be co-gasified. The levels of hard plastics present in AN and KC rejects prevent successful gasification above about $20 \mathrm{wt} \%$ blends with wood. From a paper mill's perspective it may not be economically attractive to buy large quantities of mixed wood chips even if such material is renewable and therefore eligible for renewable obligation certificates (ROC's), as price can be high and availability problematic. Reduction of the plastics content of AN and $\mathrm{KC}$ rejects by pre-treatment might be an option, but the plastics content is very high in these streams and there may not be enough residual fibrous material left to justify the gasification route. The SSK rejects on the other hand have a much lower plastics content, and their partial removal by pre-treatment might be attractive in that the need for cogasification with wood may be removed. Assuming that the results obtained from this work are scalable then rejects could be pre-treated on-site at a paper mill and used as a fuel in a $250 \mathrm{~kg} / \mathrm{hr}$ fixed bed gasifier, which would create enough producer gas to power a $250 \mathrm{kWe}$ gas engine. The exhaust gases from the engine could then be re-used for drying the feedstock. Multiple downdraft gasifier units in parallel could potentially be installed for higher tonnages of rejects. It may also be an economically attractive option to produce fibrous reject pellets for sale as a gasification fuel to existing wood gasifier plants. However, it should be recognised that the results of this study were obtained at small scale over relatively short run durations, and do not guarantee successful operation at industrial scale with several thousand hours of continuous operation.

The inclusion of de-inking sludge to the mix of rejects and mixed wood chips was observed to have little or no effect on reducing agglomeration problems caused by plastics. The level of ash present within de-inking sludge restricted its use to a maximum blend of $40 \mathrm{wt} \%$. It is thought that higher blends of this feedstock maybe possible by using a fluidised bed gasifier. Alternatively a more 
attractive option for paper mills would be to process de-inking sludge by pyrolysis. This has been proven to yield high energy pyrolysis oils which can be used in combustors, gasifiers, boilers and engines for CHP generation [17]. One advantage of processing de-inking sludge by pyrolysis as opposed to gasification is that no co-firing or support fuel is required.

\subsection{CONCLUSIONS}

In this study the fixed bed downdraft gasification of selected paper industry waste blends as a cogasified fuel with wood chips was investigated. The results show that the most promising trials were those carried out using reject waste pellets produced from Smurfit Kappa SSK brown paper mill, where as much as $80 \mathrm{wt} \%$ of the rejected pellets could be successfully co-gasified with wood chips. The limiting factor for other feedstocks and blends was the agglomeration of plastics present within the fuel causing blockage in the gasifier.

It was therefore concluded that the optimal application for this technology is at paper mills which manufacture brown paper for the corrugated board industry, using their rejects stream. Some importing of wood chips as a co-gasification fuel may be necessary, although it may be possible to eliminate this by pre-sorting the rejects to remove some of the plastics content.

\subsection{ACKNOWLEDGEMENTS}

The authors would like to thank the Engineering and Physical Science Research Council (EPSRC), Aylesford Newsprint Ltd, Smurfit Kappa SSK and Kimberly-Clark Flint for sponsoring this project.

\subsection{ROLE OF FUNDING SOURCE}

This work has been sponsored by (i) The Engineering and Physical Science Research Council (EPSRC) under an Industrial Co-operative Award in Science and Engineering (CASE) and (ii) Three UK based paper mills, Smurfit Kappa SSK, Kimberly Clark Flint and Aylesford Newsprint Ltd. The sponsoring bodies have taken no active role in the collection, analysis and interpretation of data presented, or in the writing of the article, however the content herewith has been reviewed by all of the sponsoring bodies and the full consent to its publication has been awarded.

\subsection{REFERENCES}

[1] Dunster MA. Characterisation of Mineral Wastes, Resources and Processing technologies Integrated waste management for the production of construction material. 2007; http://www.smartwaste.co.uk/filelibrary/Portland_cement_paper_sludge.pdf [Accessed 21.10.11]

[2] Kay M. The Power of Waste. Tappi J 2007; 49, 2, 21-22.

[3] Oliveira AGP, Brammer GJ. Experimental study of a throated downdraft biomass gasifier: Part 1 instrumentation for measurement of temperature and gas concentrations in the radial and longitudinal directions. In: Bridgwater AV, editor. Proceedings of the bioten conference on biomass bioenergy and biofuels 2010, Berkshire: CPL Press; 2011, p. 745-751.

[4] Ouadi M, Brammer GJ, Hornung A. Sustainable energy from paper industry wastes. In: Bridgwater AV, editor. Proceedings of the bioten conference on biomass bio energy and biofuels 2010, Berkshire: CPL Press; 2011, p. 267-278. 
511 [5] Phuphuakrat .T, Nipattummakul .N, Namioka .T, Kerdsuwan .S, Yoshikawa .K. Characterization

512 of tar content in the syngas produced in a downdraft type fixed bed gasification system from dried sewage sludge. 2010; 89, 9, 2278-2284

[6] Yoon .J.S, Son .IY, Kim .K.Y, Lee .G.J. Gasification and power generation characteristics of rice husk and rice husk pellet using a downdraft fixed bed gasifier. Renewable Energy 2012; 42, 163-167

[7] Durai-Swamy .K, Warren D.W, Mansour M.N, (1991), Indirect steam gasification of paper mill sludge waste, TAPPI Journal 1991; 74, 10, 137-143

[8] Frederick JWM, Lisa K, Lundy JR, O’Connor WK, Reis K, Scott A, et al. Energy and materials recovery from recycled paper sludge. Tappi J 1996; 79, 6, 123-131.

[9] García-Bacaicoa P., Mastral J.F., Ceamanos J., Berrueco C., Serrano S. (2008). Gasification of biomass/high density polyethylene mixtures in a downdraft gasifier. Bioresource Technology, 99, 13, $5485-5491$

[10] Channiwala SA, Parikh PP. A unified correlation for estimating HHV of solid liquid and gaseous fuels. Fuel 2002; 81,1051-1063.

[11] CEN Tar Protocol, 2005 www.tarweb.net/results/pdf/Technical-Report-version-3_8-final.pdf [accessed 17.07.10].

[12] Hong T, Shu-rong W. Experimental study of the effects of acid washing pre-treatment on biomass pyrolysis. J Fuel Chem Technol 2009; 37, 6, 668-672

[13] Piyali D, Ganesh A, Wangikar P. Influence of pretreatment for de-ashing of sugarcane bagasse on pyrolysis products. Biomass and Bioenergy 2004; 27, 5, 445-457.

[14] Wang S R, Liao Y F, Liu Q, Luo Z Y, Cen K F. Experimental study of the influence of acid wash on cellulose pyrolysis, J Fuel Chem Technol 2006; 34, 2, 179-183.

[15] U.S Department of Energy. Handbook of Biomass Downdraft Gasifier Engine systems, Washington, US Government.1988.

[16] Bhattacharya .S.C, Siddique .M.R, Pham .H.L. A study on wood gasification for low-tar gas production. Energy 1999; 24, 285-296.

[17] Ouadi .M, Brammer .G.J, Kay .M, Hornung .A. Waste to Power. Tappi J. 2012; 11(2): 55-64 
Figure 1 Aylesford Newsprint Ltd (AN) dried de-inking sludge pellets

Figure 2 Smurfit Kappa SSK brown paper mill fuel reject pellets

Figure 3 A Schematic diagram of the Gasification System

Figure 4 Producer Gas Tar Cleaning System

Figure 5 Agglomeration caused by melting of plastics ( 6 inches diameter) 


\title{
Figure
}

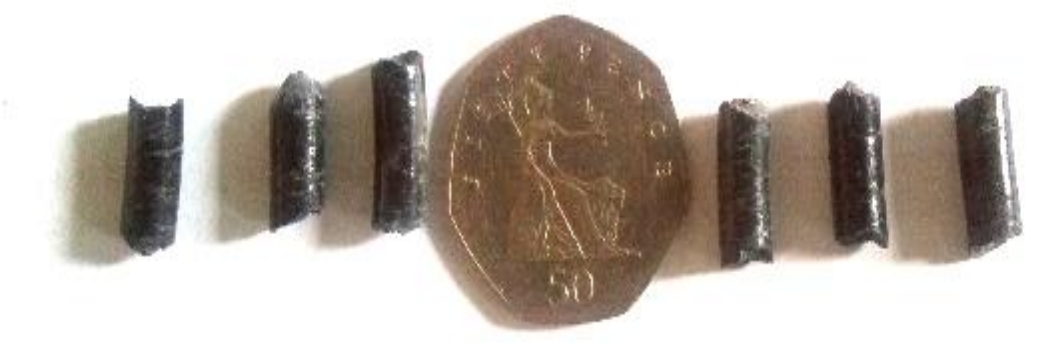

Figure 1 Aylesford Newsprint Ltd (AN) dried de-inking sludge pellets

\author{
(a)
}




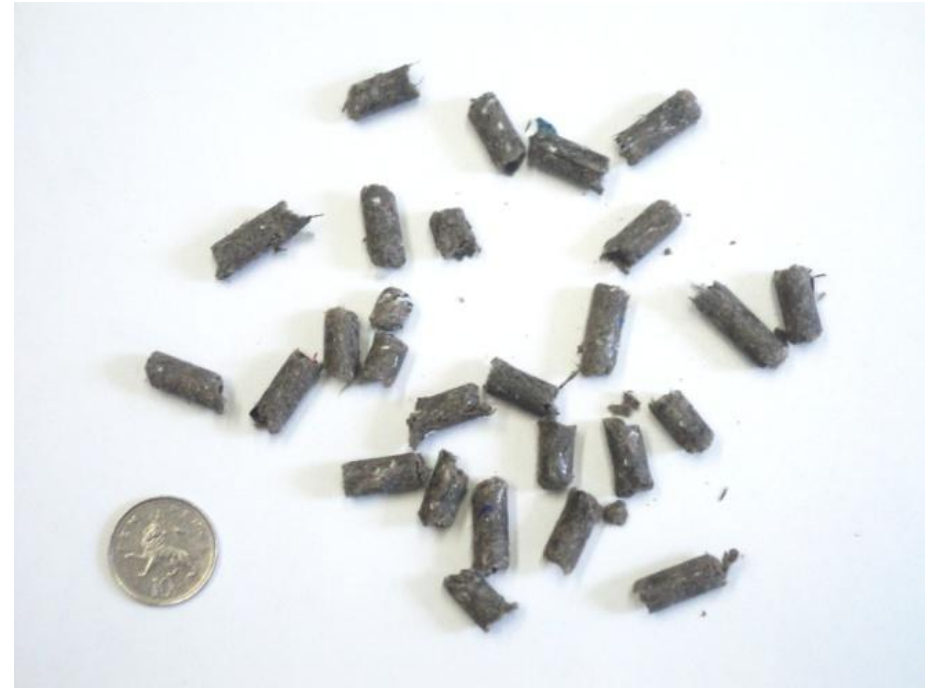

Figure 2 Smurfit Kappa SSK brown paper mill fuel reject pellets 


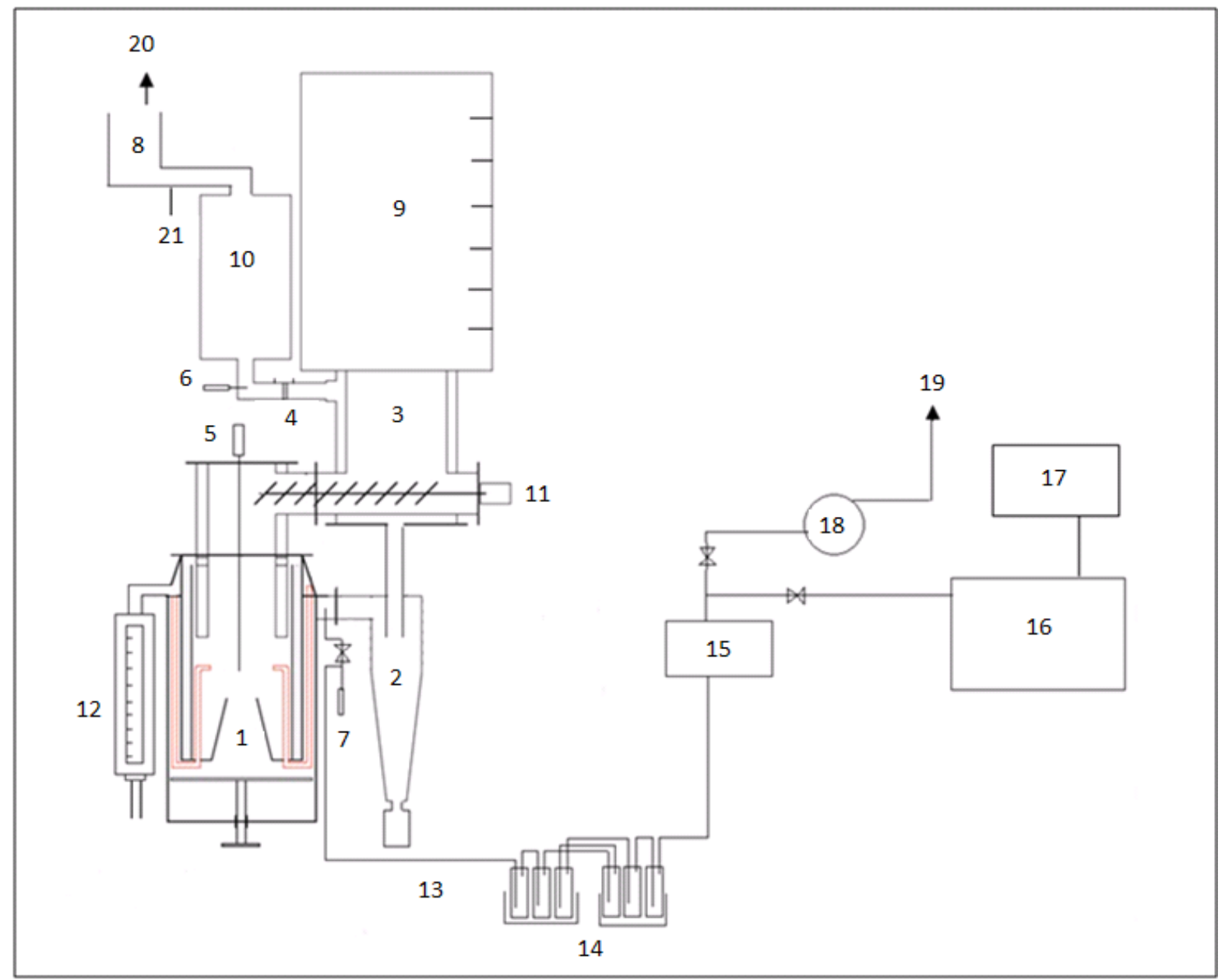

1 Gasifier, 2 Cyclone, 3 Heat Exchanger Drying Bucket, 4 Orifice Plate, 5 Thermocouple, 6 Thermocouple, 7 Thermocouple, 8 Swirl Burner, 9 Calibrated Glass Hopper, 10 Carbon Absorption Filter, 11 Auger , 12 Air Rotameter, 13 Gas Sampling Line, 14 Gas Wash Bottles, 15 Digital Mass Flowmeter, 16 Gas Chromatograph, 17 Computor, 18 Gas Suction Pump, 19 Vent, 20 Main Vent, 21 Venturi Ejector

Figure 3 A Schematic diagram of the Gasification System 


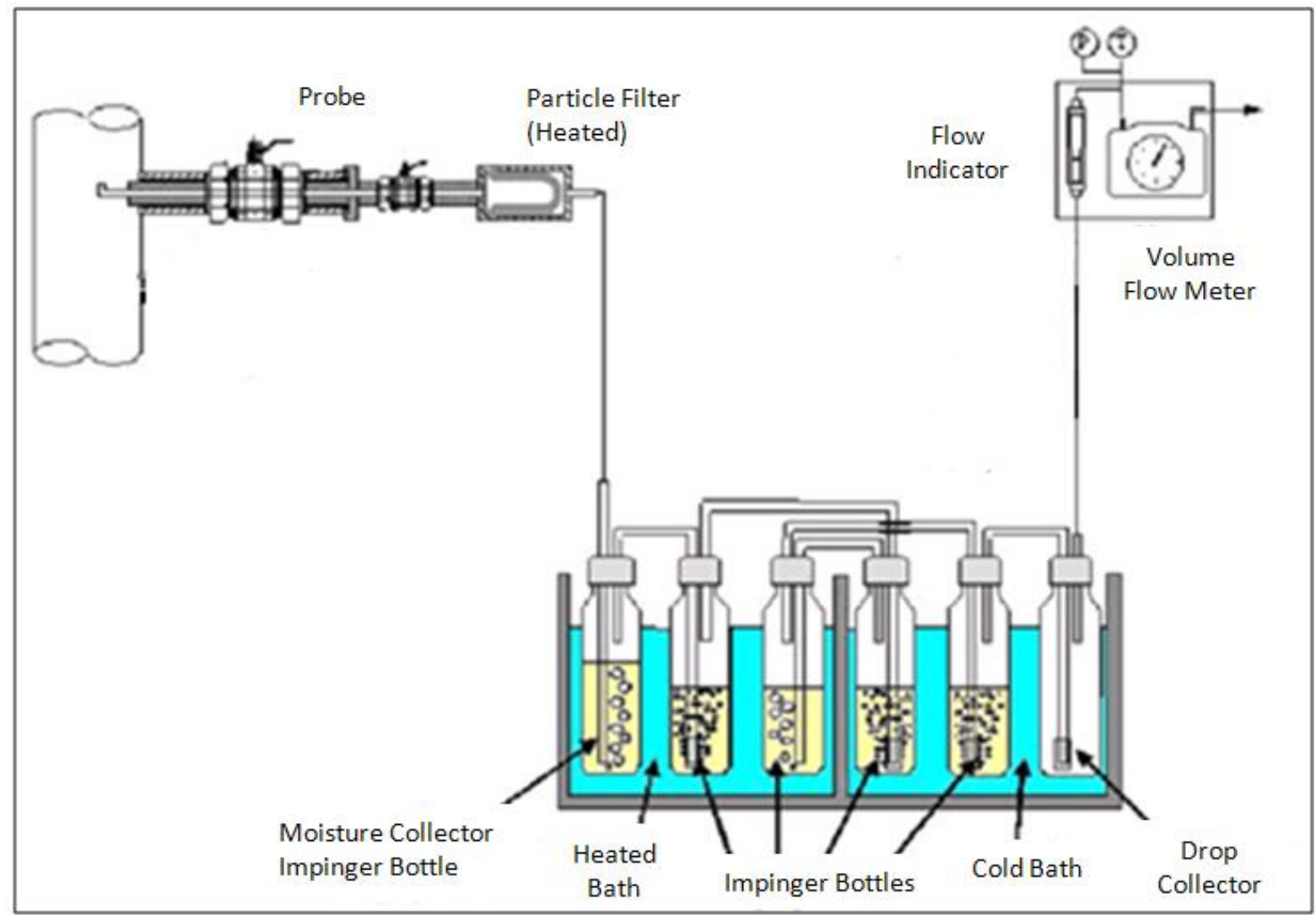

Figure 4 [9] Producer Gas Tar Cleaning System 


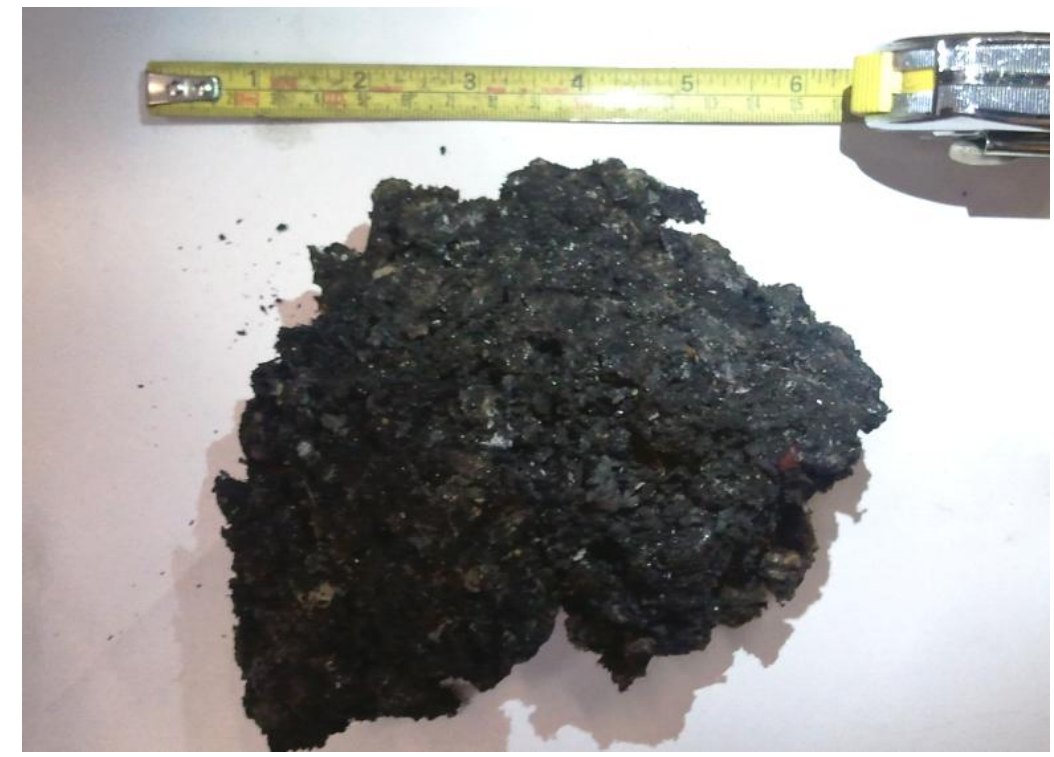

Figure 5 Agglomeration caused by melting of plastics (6 inches diameter) 


\begin{tabular}{cccccccc}
\hline & $\begin{array}{c}\text { Mixed } \\
\text { Wood } \\
\text { Chips }\end{array}$ & $\begin{array}{c}\text { Aylesford } \\
\text { Newsprint } \\
\text { De-inking } \\
\text { Sludge }\end{array}$ & $\begin{array}{c}\text { Kimberly } \\
\text { Clark Flint } \\
\text { Pulper } \\
\text { Reject } \\
\text { Pellets }\end{array}$ & $\begin{array}{c}\text { Kimberly } \\
\text { Clark Flint } \\
\text { Dry Coform } \\
\text { Reject } \\
\text { Pellets }\end{array}$ & $\begin{array}{c}\text { Kimberly } \\
\text { Clark Flint } \\
\text { Wet Coform } \\
\text { Reject } \\
\text { Pellets }\end{array}$ & $\begin{array}{c}\text { Aylesford } \\
\text { Newsprint } \\
\text { Pulper } \\
\text { Reject } \\
\text { Pellets }\end{array}$ & $\begin{array}{c}\text { Smurfit } \\
\text { Kappa SSK } \\
\text { Pulper } \\
\text { Reject } \\
\text { Pellets }\end{array}$ \\
\hline $\begin{array}{c}\text { Proximate Analysis } \\
\text { wt\% (dry basis) }\end{array}$ & & & & & & & \\
Moisture & 3.7 & 1 & 2.0 & 2.5 & 9.5 & $<0.2$ & 7.6 \\
Volatiles & 86.6 & 46.3 & 82.2 & 82.7 & 79.5 & 83.4 & 73.5 \\
Fixed Carbon & 9.4 & 1.1 & 9.1 & 7.7 & 7.4 & 7.2 & 10.1 \\
Ash & 0.3 & 51.6 & 6.7 & 4.1 & 3.6 & 9.4 & 8.8 \\
Gross HV (MJ/Kg) & 15.4 & 6.4 & 24.8 & 20.4 & 20.4 & 18.3 & 22.9 \\
\hline Ultimate Analysis & & & & & & & \\
wt\% (dry basis) & & & & & & & \\
Carbon & 45.6 & 21.1 & 70.5 & 58.9 & 60.4 & 60.9 & 53.3 \\
Hydrogen & 5.8 & 2.3 & 8.3 & 6.1 & 6.4 & 3.4 & 7.5 \\
Oxygen* & 48.0 & 24.7 & 13.9 & 30.2 & 28.8 & 23.5 & 29.6 \\
Nitrogen & 0.3 & 0.3 & 0.5 & 0.4 & 0.6 & 0.4 & 0.5 \\
Sulphur & $<0.1$ & $<0.1$ & $<0.1$ & 0.2 & 0.2 & 0.4 & $<0.1$ \\
Chlorine & $<0.1$ & $<0.1$ & 0.1 & 0.1 & $<0.1$ & 2 & 0.3 \\
\hline
\end{tabular}

Table 1 Proximate, Ultimate and Heating Value Compositions of Feedstocks 


\begin{tabular}{crc}
\hline $\begin{array}{c}\text { Trial } \\
\text { Number }\end{array}$ & Feedstock Blend (wt\%) & Status \\
\hline 1 & $20 \%$ AN Pulper Reject Pellets, 80\% Wood Chips & Successful \\
2 & $50 \%$ AN Pulper Reject Pellets, 50\% Wood Chips & Unsuccessful \\
3 & $30 \%$ AN Pulper Reject Pellets, 70\% Wood Chips & Unsuccessful \\
4 & $10 \%$ AN Pulper Reject Pellets, 10\% De-inking Sludge, 80\% Wood Chips & Successful \\
5 & $15 \%$ AN Pulper Reject Pellets, 20\% De-inking Sludge, 65\% Wood Chips & Successful \\
6 & $10 \%$ AN Pulper Reject Pellets, 40\% De-inking Sludge, 50\% Wood Chips & Successful \\
7 & $20 \%$ SSK Pulper Reject Pellets, 80\% Wood Chips & Successful \\
8 & $50 \%$ SSK Pulper Reject Pellets, 50\% Wood Chips & Successful \\
9 & $70 \%$ SSK Pulper Reject Pellets, 30\% Wood Chips & Successful \\
10 & $80 \%$ SSK Pulper Reject Pellets, 20\% Wood Chips & Successful \\
11 & $100 \%$ SSK Pulper Reject Pellets & Unsuccessful \\
12 & $41 \%$ KC Pulper Reject Pellets, 15\% Wet Co-form, 11\% Dry Co-form, 33\% Wood Chips & Unsuccessful \\
\hline
\end{tabular}

Table 2 Feedstock blends tested and gasification performance 


\begin{tabular}{|c|c|c|c|c|c|c|c|c|}
\hline $\begin{array}{c}\text { Trial } \\
\mathbf{N}^{\circ}\end{array}$ & Feedstock Blend (Wt \%) & $\mathbf{H}_{2}$ & $\mathbf{N}_{2}$ & $\mathrm{CO}$ & $\mathrm{CH}_{4}$ & $\mathrm{CO}_{2}$ & $\begin{array}{l}\text { Gas H.V } \\
\left(\mathrm{MJ} / \mathrm{Nm}^{3}\right)\end{array}$ & $\begin{array}{c}\text { Air } \\
\text { Equivalence } \\
\text { Ratio } \\
\end{array}$ \\
\hline 1 & $20 \%$ AN Reject Pellets, $80 \%$ Wood Chips, & 16.16 & 45.04 & 24.43 & 2.42 & 11.94 & 6.3 & 0.36 \\
\hline 4 & $\begin{array}{c}10 \% \text { AN Reject Pellets, } \\
10 \% \text { De-inking Sludge, } 80 \% \text { Wood Chips, }\end{array}$ & 14.41 & 47.27 & 24.35 & 2.16 & 11.80 & 6 & 0.53 \\
\hline 5 & $\begin{array}{c}15 \% \text { AN Reject Pellets } \\
20 \% \text { De-inking Sludge, } 65 \% \text { Wood Chips, }\end{array}$ & 15.00 & 47.46 & 24.73 & 0.94 & 11.87 & 4.2 & 0.36 \\
\hline 6 & $\begin{array}{c}10 \% \text { AN Reject Pellets } \\
40 \% \text { De-inking Sludge, } 50 \% \text { Wood Chips }\end{array}$ & 11.50 & 49.67 & 21.79 & 1.59 & 15.43 & 5 & 0.27 \\
\hline 7 & $20 \%$ SSK Reject Pellets, $80 \%$ Wood Chips & 11.00 & 51.49 & 19.09 & 2.31 & 16.11 & 4.9 & 0.28 \\
\hline 8 & $50 \%$ SSK Reject Pellets, 50\% Wood Chips & 17.74 & 38.08 & 35.02 & 2.17 & 6.99 & 8 & 0.24 \\
\hline 9 & $70 \%$ SSK Reject Pellets, $30 \%$ Wood Chips & 16.64 & 50.44 & 24.53 & 1.51 & 6.88 & 6 & 0.34 \\
\hline 10 & $80 \%$ SSK Reject Pellets, $20 \%$ Wood Chips & 16.24 & 42.49 & 23.34 & 5.21 & 12.71 & 7.3 & 0.22 \\
\hline
\end{tabular}

Table 3 Producer Gas Volume Compositions of Successful Gasification Trials (v/v \%) 


\begin{tabular}{cccc}
\hline $\begin{array}{c}\text { Trial } \\
\mathbf{N}\end{array}$ & Feedstock Blend (wt\%) & $\begin{array}{c}\text { Tar } \\
\left(\mathrm{g} / \mathrm{Nm}^{3}\right)\end{array}$ & $\begin{array}{c}\text { Water } \\
\left(\mathrm{g} / \mathrm{Nm}^{3}\right)\end{array}$ \\
\hline 1 & 20\% AN Reject Pellets, 80\% Wood Chips & 3.78 & 16.7 \\
4 & $10 \%$ AN Reject Pellets, 10\% De-inking Sludge, 80\% Wood Chips & 2.15 & 11 \\
5 & 15\% AN Reject Pellets, 20\% De-inking Sludge, 65\% Wood Chips & 4.8 & 15.6 \\
6 & 10\% AN Reject Pellets, 40\% De-inking Sludge, 50\% Wood Chips & 1.9 & 15.52 \\
7 & 20\% SSK Reject Pellets, 80\% Wood Chips & 2 & 21 \\
8 & $50 \%$ SSK Reject Pellets, 50\% Wood Chips & 0.89 & 6.43 \\
9 & $70 \%$ SSK Reject Pellets, 30\% Wood Chips & 4.4 & 70.2 \\
10 & $80 \%$ SSK Reject Pellets, 20\% Wood Chips & 5.8 & 21 \\
\hline
\end{tabular}

Table 4 Tar and Water Condensate 


\begin{tabular}{|c|c|c|c|c|c|c|c|c|c|}
\hline & \multicolumn{3}{|c|}{ In (Kg/hr) } & \multicolumn{5}{|c|}{ Out (Kg/hr) } & Closure \\
\hline Feedstock Blend (wt\%) & Air & Feed & Tot & Ash & Gas & $\mathrm{H}_{2} \mathrm{O}$ & Tar & Tot & $\%$ \\
\hline $20 \%$ AN Reject Pellets, $80 \%$ Wood Chips & 7.39 & 3.70 & 11.09 & 0.08 & 9.26 & 0.17 & 0.04 & 9.55 & 86 \\
\hline $\begin{array}{c}10 \% \text { AN Reject Pellets, } 10 \% \text { De-inking Sludge, } \\
80 \% \text { Wood Chips }\end{array}$ & 11.28 & 4.22 & 15.50 & 0.27 & 13.46 & 0.14 & 0.03 & 13.90 & 90 \\
\hline $\begin{array}{l}\text { 15\% AN Reject Pellets, 20\% De-inking Sludge, } \\
65 \% \text { Wood Chips }\end{array}$ & 9.21 & 5.27 & 14.48 & 0.63 & 17.34 & 0.30 & 0.09 & 18.37 & 127 \\
\hline $\begin{array}{c}10 \% \text { AN Reject Pellets, } 40 \% \text { De-inking Sludge, } \\
50 \% \text { Wood Chips }\end{array}$ & 11.28 & 10.26 & 21.54 & 2.25 & 19.02 & 0.33 & 0.04 & 21.64 & 100 \\
\hline $20 \%$ SSK Reject Pellets, $80 \%$ Wood Chips & 7.33 & 4.63 & 11.96 & 0.09 & 11.65 & 0.27 & 0.03 & 12.05 & 101 \\
\hline 50\% SSK Reject Pellets, 50\% Wood Chips & 10.94 & 7.14 & 18.08 & 0.32 & 19.26 & 0.16 & 0.02 & 19.77 & 109 \\
\hline $70 \%$ SSK Reject Pellets, $30 \%$ Wood Chips & 13.32 & 5.74 & 19.06 & 0.36 & 22.79 & 2.06 & 0.13 & 25.35 & 133 \\
\hline $80 \%$ SSK Reject Pellets, $20 \%$ Wood Chips & 8.43 & 5.62 & 14.02 & 0.4 & 13.5 & 0.33 & 0.09 & 14.32 & 102 \\
\hline
\end{tabular}

Table 5 Gasification Mass Balance $(\mathrm{Kg} / \mathrm{hr})$ 